\title{
Population biology of the subtidal kelps Macrocystis integrifolia and Lessonia trabeculata (Laminariales, Phaeophyceae) in an upwelling ecosystem of northern Chile: interannual variability and El Niño 1997-1998
}

\author{
Biología poblacional de huirales submareales de Macrocystis integrifolia y Lessonia \\ trabeculata (Laminariales, Phaeophyceae) en un ecosistema de surgencia del norte de \\ Chile: variabilidad interanual y El Niño 1997-1998
}

\author{
J.M. ALONSO VEGA ${ }^{1,2}$, JULIO A. VÁSQUEZ ${ }^{1,2, *}$ \& ALEJANDRO H. BUSCHMANN ${ }^{3}$ \\ ${ }^{1}$ Departamento de Biología Marina, Facultad de Ciencias del Mar, Universidad Católica del Norte, \\ ${ }^{2}$ CEAZA, Centro de Estudios Avanzados de Zonas Áridas, Casilla 117, Coquimbo, Chile \\ ${ }^{3}$ I-MAR, Universidad de Los Lagos, Casilla 557, Puerto Montt, Chile \\ *Autor para correspondencia: e-mail: jvasquez@ucn.cl
}

\begin{abstract}
This paper describes the population biology of Lessonia trabeculata and Macrocystis integrifolia during and after the 1997-1998 El Niño in an area of permanent coastal upwelling in northern Chile. Spatial and temporal patterns of distribution were evaluated seasonally for adult and juvenile sporophytes of both species between 1996 and 2003. These two kelp form an assemblage distributed between 2 and $15 \mathrm{~m}$ depth, with disjunct patterns along a bathymetric gradient, including two morphs of L. trabeculata, the occurrence of which depends on the presence or absence of M. integrifolia. During the 1997-1998 El Niño the spatial-temporal patterns of abundance of the kelp assemblage were maintained by the continuity of coastal upwelling, which buffered and moderated superficial warming of the sea and depletion of nutrients. In this context, localities associated with coastal upwelling areas could function as "sources" of reproductive propagules after passage of El Niño, thus increasing kelp recolonization rates in "sink" localities, which suffered local kelp extinctions. Intensification of upwelling processes after the 1998-2000 La Niña increased nutrient inputs into subtidal habitats, favoring the productivity of the kelp assemblage. However, an abrupt change in the spatial-temporal patterns of abundance of the black sea urchin Tetrapygus niger, the most conspicuous benthic grazer in northern Chile, produced local extinctions of M. integrifolia and compression of the range of bathymetric distribution of L. trabeculata. Top-down (mortality of benthic carnivores during the 1997-1998 El Niño) and bottom-up effects (intensity and frequency of upwelling) in this subtidal coastal ecosystem appear to regulate the kelp-herbivore interactions in the study area. The main sources of reproductive propagules for the reestablishment of the assemblage kelp were fertile sporophytes which included isolated, low density patches of M.integrifolia located within the bed of L. trabeculata, although drifting kelp rafts and "seed banks" of microscopic dormant stages may provide supplementary recruitment. In the temperate SE Pacific, oceanographic events that act on different spatial-temporal scales plus low frequency biological processes (changes in grazer abundance), which act on local scales, produce inter-annual variability in the long-term dymanics of kelp populations. Furthermore, the interactive effects between centers of permanent upwelling and the oscillating temporal periodicity of oceanographic events that produce positive (El Niño) and negative (La Niña) thermal anomalies modify the spatial arrangement of subtidal kelp populations on a latitudinal gradient.
\end{abstract}

Key words: subtidal habitats, population and community ecology, extinction and re-colonization processes, kelp-herbivore interaction, El Niño, La Niña.

\section{RESUMEN}

Este trabajo describe la biología poblacional de Macrocystis integrifolia y Lessonia trabeculata durante y después de El Niño 1997-1998, en un área de surgencia costera permanente en el norte de Chile. Los patrones de distribución espacio-temporales de esporofitos adultos y juveniles de ambos huiros fueron evaluados estacionalmente entre 1996 y 2003. Ambos huiros conforman un ensamble que se distribuye entre 2-15 m de profundidad con patrones disjuntos a lo largo del gradiente batimétrico, y con dos 
morfos de L. trabeculata que dependen de la presencia o ausencia de M. integrifolia. Durante El Niño 1997-1998, los patrones espacio-temporales de abundancia del ensamble de huiros son mantenidos por la continuidad de los procesos de surgencia costera que amortiguan y moderan el calentamiento superficial del mar y la disminución de nutrientes. En este contexto, después de un evento El Niño las localidades asociadas a áreas con surgencia permanente pueden funcionar como áreas "fuentes" productora de propágulos reproductivos incrementando la tasa de recolonización en áreas "sumideros" adyacentes donde se produjo extinción local de huiros. Durante La Niña 1998-2000, la intensificación de los procesos de surgencia incrementa la entrada de nutrientes hacia hábitat submareales favoreciendo la productividad del ensamble de huiros. Sin embargo, un repentino cambio en los patrones espaciotemporales de Tetrapygus niger (erizo negro), el pastoreador bentónico más conspicuo del norte de Chile, produjo la extinción local de $M$. integrifolia y la compresión del rango de distribución batimétrica de $L$. trabeculata. Efectos cascada abajo (mortalidad de carnívoros bentónicos durante El Niño 1997-1998) y cascada arriba (intensidad y frecuencia de surgencia) en este ecosistema submareal costero parecen regular la interacción huiros-herbívoros en el área de estudio. La principal fuente productora de propágulos para el reestablecimiento del ensamble proviene de esporofitos fértiles que configuran parches aislados de baja densidad de $M$. integrifolia ubicados dentro de la pradera de L. trabeculata, aunque huiros flotando a la deriva y "bancos de semilla" de estados latentes microscópicos podrían actuar como estrategias complementarias. En el Pacífico Sudamericano temperado, eventos oceanográficos que actúan a distintas escalas espacio-temporales y procesos biológicos estocásticos de baja frecuencia (cambios en la abundancia de pastoreadores) que actúan a escala local, generan variabilidad interanual en la dinámica de las poblaciones de huiros a largo plazo. Además, el efecto interactivo entre centros de surgencia permanente y la periodicidad temporal oscilatoria de eventos oceanográficos que generan anomalías térmicas positivas (El Niño) y negativas (La Niña) modifican el arreglo espacial de las poblaciones submareales de huiros en el gradiente latitudinal.

Palabras clave: hábitat submareales, ecología de poblaciones y comunidades, procesos de extinción y recolonización, interacción planta-herbívoro, El Niño, La Niña.

\section{INTRODUCTION}

The spatial-temporal patterns of kelp assemblages are generally determined by the diversity and population biology of the constituent species (Dayton et al. 1999). Seasonality of physical (e.g., temperature, water movement, quantity and quality of light) and chemical (e.g., nutrients) parameters are important in the regulation of reproductive and vegetative processes of specific components within kelp assemblages (Graham et al. 1997, Hernández-Carmona et al. 2001, Buschmann et al. 2004), and may covary in subtidal environments to produce synergistic interactions (Kain 1989). Conversely, biological processes such as inter- and intraspecific competition, pest and herbivory regulate kelp assemblage structure, modifying spatial and temporal patterns of species abundance (Dayton 1985, Vásquez \& Buschmann 1997, Scheibling et al. 1999), and morphology (Vásquez 1991).

Long-term studies in the Northern Hemisphere have shown that El Niño Southern Oscillation events (ENSO), which include alternation of a warm phase (El Niño) with a cold phase (La Niña), alter the structure and organization of subtidal kelp in temperate latitudes, modifying patterns of persistence, stability, succession, species diversity, and abundance (Dayton et al. 1992, 1999, Tegner et al. 1997). In the Southern Hemisphere, depending on the magnitude and intensity, El Niño can produce localized kelp extinctions (Camus 1994) and subsequent re-colonization that modify the spatial-temporal distribution and abundance of local populations (Camus et al. 1994, Martínez et al. 2003). Still, most studies of subtidal kelp population biology in the Southern Hemisphere are short-term (one year, see Vásquez 1993, Camus 1994, Buschmann et al. 2004, Tala et al. 2004), or are limited to high latitudes ( $\geq 40^{\circ} \mathrm{S}$ ), where the influence of ENSO is minimal (Moreno \& Sutherland 1982, Santelices \& Ojeda 1984, Dayton 1985). As such, there are no long-term data concerning the effects of large-scale, low frequency events such as ENSO on kelp population biology. These oceanographic events are probably important in regulating interannual variability in the northern Chile biogeographic region (ca. $18-30^{\circ} \mathrm{S}$, see Camus 1990, Vásquez et. al. 1998).

The persistence of kelp populations on the northern Chilean coast during and after El Niño has been associated with coastal upwelling located at specific geographic areas (Martínez 
1999). One of the most important coastal upwelling centers of northern Chile is located

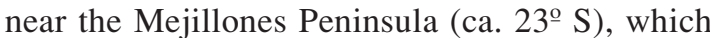
is seasonal, and related to the annual cycle of driving winds from the SW (Escribano et al. 2004). In this region, one of the main water masses being upwelled is that of Equatorial Subsuperficial Water (ESSW), characterized by low dissolved oxygen concentrations, low temperatures, and high concentration of nutrients (González et al. 1998). These water masses are transported shoreward by poleward flow in the first $200 \mathrm{~m}$ (Marín et al. 2001, Escribano et al. 2004). Interest in the Mejillones Peninsula sector has increased markedly in recent decades because some studies have reported that subsuperficial upwelling occurs in the area year round (Fonseca \& Farias 1987, Escribano 1998). This promotes continuous, high primary and secondary production in the water column (Marin et al. 1993, Escribano \& McLaren 1999, Fernández et al. 2002) as well as in the shoal litoral benthos (Vásquez et al. 1998, Camus \& Andrade 2001), even during superficial warming generated by El Niño (González et al. 2000, Ulloa et al. 2001, Vásquez \& Vega 2004).

On the northern coast of Chile (ca. $23^{\circ} \mathrm{S}$ ), the 1997-1998 El Niño occurred as two pulses of positive thermal anomaly at the surface and sea level associated with strong poleward flows in the first $100 \mathrm{~m}$ (Takesue et al. 2004). The thermocline/oxycline and nutricline that normally rise to $40-60 \mathrm{~m}$ were depressed to 150-200 m depths between April and May 1997, and between Novembre 1997 and January 1998 (Ulloa et al. 2001). The 1997-1998 El Niño was immediately followed by La Niña conditions, characterized by a mild and moderate cooling of the water during 19981999 , with cooling of greater intensity in 19992000 (Takesue et al. 2004). The 1998-2000 La Niña promoted the emergence of SW winds driving coastal upwelling, and intensifying the upsurge of subsuperficial water in the area of the Mejillones Peninsula (Lagos et al. 2002). The transition to a cold, nutrient-rich condition (La Niña) following a high-intensity warming event (El Niño) facilitates and increases the local recovery rates of kelp assemblages and their associated communities (Edwards 1994, Martínez et al. 2003). Within this context, a long term monitoring program of subtidal kelp at a site on the Mejillones Peninsula (beginning in 1996) permitted evaluation of the interactive effects of the ENSO cycle (1997-1998 El Niño and 1998-2000 La Niña events) and effects of coastal upwelling on the population biology of South American subtidal kelps.

In Chile, between 18 and $32^{\circ} \mathrm{S}$, two kelp species, Macrocystis integrifolia Bory and Lessonia trabeculata Villouta et Santelices, coexist in subtidal rocky environments, forming a broad subtidal assemblage from the intertidal to $15-20 \mathrm{~m}$ depths (Alveal et al. 1973, Vásquez et al. 2001). Both kelps have biphasic heteromorphic life cycles, with alternation of a microscopic gametophytic (n) generation, which is short lived, and a long-lived macrophytic perennial sporophytic generation (2n) (Buschmann et al. 2004, Tala et al. 2004). While there are some reports in the literature regarding the population biology of L. trabeculata (Villouta \& Santelices 1984, Vásquez 1991, 1992, 1993, Tala et al. 2004), data are scarce on the population biology of $M$. integrifolia and the $M$. integrifolia - L. trabeculata assemblage. The available information is restricted only to evaluations of standing stock at some localities and observations on reproductive activity in controlled environments and in the field (Dieck 1993, Buschmann et al. 2004). In this context, the present study evaluated aspects of the population biology of the subtidal kelp assemblage formed by the canopy kelp $M$. integrifolia and the bottom kelp L. trabeculata in an area of intense upwelling in northern Chile. Specifically, we considered sporophyte distribution, abundance and reproductive phenology of both species. These data are the first to address the effects of the ENSO cycle (1997-1998 El Niño and 1998-2000 La Niña) on the South American subtidal kelp assemblage, and are contrasted with the effects of other El Niño events documented in both hemispheres.

\section{MATERIAL AND METHODS}

\section{Study area}

The density and reproductive phenology of $M$. integrifolia and L. trabeculata were evaluated on a seasonal basis between July 1996 and October 2003 at Caleta Constitución, on the Mejillones Peninsula (Fig. 1). This locality is 
within a bay, which is semi-protected from dominant SW winds and waves by the presence of Santa María Island. The basal stratum of the subtidal kelp assemblage is composed of various foliose, turf, and crustose macroalgae. The macroalgae include crustose Corallinales, turfs of Gelidiales and/or Ceramiales, and often patches of Halopteris spp., Glossophora kunthii (C. Ag.) J. Ag., Asparagopsis armata Harley and Rhodymenia spp. and Chondrus canaliculatus (C. Ag.) Grev. (Vásquez et al. 2001). Detailed descriptions of the study site and the marine ecosystem are given by Vásquez et al. (1998) and Vásquez \& Vega (2004).

\section{Oceanographic conditions}

Mean daily in situ water temperature values were obtained using continuous-register thermographs (Onset Computer Corporation, Bourne, Maine, USA) placed at three meter depth along the shoal boundary of the kelp assemblage. When in situ records of oceanographic variables were discontinued, large-scale climatic indexes were used, which permitted description of oceanographic conditions, and provided approximations of ecological processes that acted on smaller scales (Stenseth et al. 2003). Here, warm and

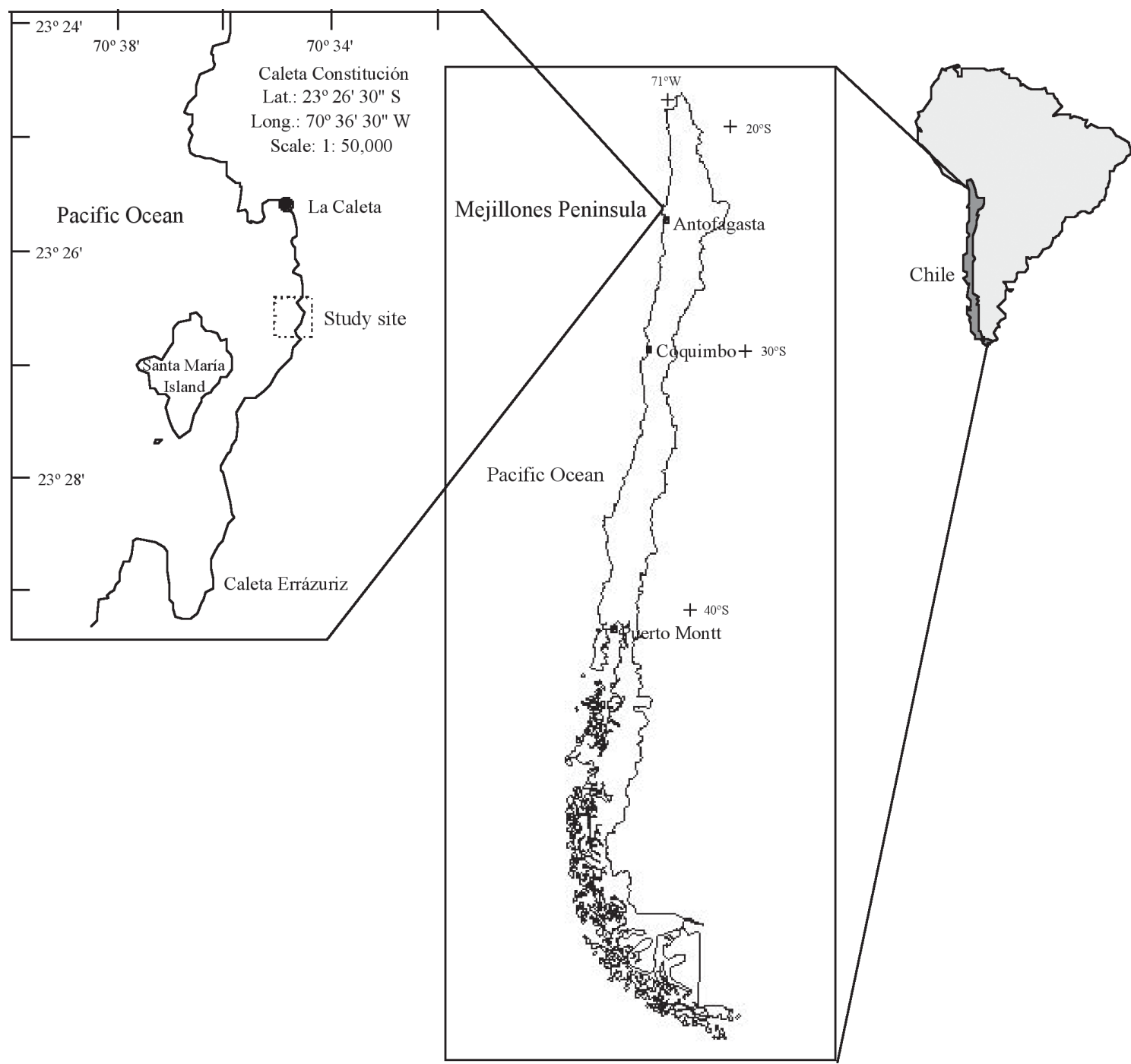

Fig. 1: Geographic location of the study area.

Ubicación geográfica del área de estudio. 
cool phases of the ENSO were determined using monthly averages of the the Southern Oscillation Index (SOI) and the Multivariate El Niño Index (MEI) for the study period (19962003), from the Bureau of Metereology, Australia (www.bom.gov.au/climate/current/) and Climate Diagnostic Center of NOAA (www.cdc.noaa.gov/ kew/MEI/mei.html), respectively. Information on the temporal variability of upwelling events in the region (23-25은 $\mathrm{S}$ ), was obtained from the monthly average index of upwelling (offshore Eckman transport, OET) between 1996 and 2001, obtained from the Pacific Environmental Laboratory (PFEL, (www.pefg.noaa.gov/ products/PFELindices.html). A detailed description of this calculation, and characteristics of the area of influence of the SOI, MEI and OET indexes have been presented by Navarrete et al. (2002).

Patterns of distribution and abundance of subtidal kelp assemblages

The spatial distribution of populations of $M$. integrifolia and L. trabeculata was evaluated seasonally (four times a year including summer, fall, winter, and spring) using four permanent transects laid perpendicular to the coast between the shoreline and $15 \mathrm{~m}$ depth, including the entire ranges of distribution of the kelp assemblage. The transects were $160 \mathrm{~m}$ in length and one meter in width, and were subdivided every $10 \mathrm{~m}$ to give 17 sampling units of $10 \mathrm{~m}^{2}$. Juvenile and adult sporophytes were counted in each sampling unit. Juvenile sporophytes of $M$. integrifolia y L. trabeculata were plants with up to two lanceolate and laminar fronds without reproductive structures, and maximum holdfast diameter of $\leq 1 \mathrm{~cm}$. Sporophyte densities were expressed as the number of sporophytes per $10 \mathrm{~m}^{2}$. Fertile sporophytes were recognized by the presence of sori on the sporophylls of $M$. integrifolia, or on the fronds of $L$. trabeculata.

The relative abundance and cover on different types of substrate in the study area were visually estimated in each sampling unit at the time of each seasonal sampling in order to estimate the abundance of substrate suitable for settlement of reproductive propagules. Substrate classifications included: (1) "barren ground" dominated by crustose calcareous coralline algae and two species of sea urchins (Tetrapygus niger Molina and Loxechinus albus Molina), (2) boulder fields, (3) consolidated rock, and (4) shell sand. The abundance of kelp species on the different substrates was also quantified.

Morphological variability of Lessonia trabeculata in the subtidal kelp assemblages

From 1996-1999, a total of 209 M. integrifolia and 203 L. trabeculata sporophytes were sampled haphazardly from each kelp bed. Also, 46 L. trabeculata sporophytes from below the canopy of $M$. integrifolia were randomly sampled, to contrast their morphologies with sporophytes collected from monospecific stands of $L$. trabeculata. Five morphological variables were determined after Vásquez (1991); these included the maximum diameter $(\mathrm{cm})$ and weight $(\mathrm{g})$ of holdfasts, the number of stipes, total plant length $(\mathrm{cm})$ and total drained wet weight $(\mathrm{kg})$ for each plant.

\section{Kelp-herbivore interactions}

The most conspicuous herbivorous grazer in the shallow rocky subtidal zone of the study site (and northern of Chile) is the sea urchin Tetrapygus niger (Vásquez \& Buschmann 1997). Temporal changes in density of this species, related to the 1997-1998 El Niño and 1998-2000 La Niña, were determined by seasonal evaluation of 64 quadrats of $0.25 \mathrm{~m}^{2}$ each, using steel frames haphazardly tossed among the perpendicular transects described above. The densities of sea urchins were expressed as the number of individuals per $\mathrm{m}^{2}$. A correlation analysis between the average densities of the herbivores T. niger and L. albus (another sea urchin frequent in the area, but less abundant; Vásquez \& Vega 2004) and the average densities of $M$. integrifolia and $L$. trabeculata, was carried out to evaluate the potential effect of herbivory on the spatiotemporal patterns and interannual variation in abundance of kelps.

\section{Statistical methods}

A nested analysis of variance (ANOVA) using the year as the main variable and seasons of the year as nested factors was used to evaluate the 
hypothesis that ENSO generated interannual variability in patterns of abundance of $M$. integrifolia and L. trabeculata. For this, transects were considered as replicates, averaging the $10 \mathrm{~m}^{2}$ quadrats within each transect. The nested analyses of variance (ANOVA) was done after visual determination of normality of the data and homocedasticity of variances by means of Bartlett tests (Sokal \& Rohlf 1981), using SYSTAT 8.0 ${ }^{\circledR}$ computational software for Windows; transformations (Log abundance +1 ) were applied when necessary to improve homoscedasticity (Sokal \& Rohlf 1981). An a posteriori Tukey test (Sokal \& Rohlf 1981) was used order to determine which groups differed from others. The year 2000 was excluded from the analyses of abundance of juveniles of $M$. integrifolia since no juveniles were found that year. The relationship between population variables and the substrate, and herbivore abundance (sea urchins) was examiend using Pearson correlation analyses (Sokal \& Rohlf 1981).

A multivariate discriminate function analysis was applied to compare morphologies of the L. trabeculata sporophytes between inside and outside of the $M$. integrifolia canopy using SYSTAT 8.0. Discriminat analysis has been previously used to evaluate morphological variability between populations of M. integrifolia (Druehl 1978, Druehl \& Kemp 1982).

\section{RESULTS}

\section{Oceanographic conditions}

The in situ sea temperature showed a seasonal pattern, with warm water between December and March (summer) and cool water between June and September (winter) (Fig. 2A). During the study period between April 1997 and March 1998 the seawater was unusually warm, with maximum positive thermal anomalies fluctuating between +2 and $+2.5{ }^{\circ} \mathrm{C}$. An exception occurred between August and November 1997 when upwelling events lowered the seawater temperatures, interrupting the anomalous warm period. Immediately afterward, beginning in April 1998, cooling of the water began with weak, moderate, and strong La Niña event when the seawater anomaly ranged between -0.5 and $-1.5{ }^{\circ} \mathrm{C}$ until the end of 2000 (Fig. 2A). The southern oscillation index (SOI, Fig. 2B) and the multivariate El Niño index (MEI, Fig. 2B) showed normal conditions in 1996 lasting until summer 1997. The El Niño event was clear between May 1997 and March 1998, coinciding with the thermal anomaly detected by the in situ temperature records (Fig. 2A). Following the nearly normal, weakly-cold period of 1998 2000, a new warmer period was observed between April 2002 and April 2003, which was of low to moderate intensity (Fig. 2B), casusing a positive thermal anomaly of $1{ }^{\circ} \mathrm{C}$. Mean values for the upwelling index (OET) were always positive during the study period, showing the persistence over time of offshore Ekman transport conditions in the region (Fig. 2C). The upwelling index showed greater offshore transport between September and December (spring), and lower intensities between April and July (Fig. 2C). The highest upwelling activity occurred during the spring of 1996, decreasing significantly in May 1997 at the beginning of the 1997-1998 El Niño. Nevertheless, the Ekman transport remained active, constant, and intense between July 1997 and February 1998 (Fig. 2C) during the maximum thermal anomalies of the 1997-1998 El Niño (see also Ulloa et al. 2001, Navarrete et al. 2002).

Patterns of spatial distribution of subtidal kelp assemblages

Under "normal" oceanographic conditions (winter 1996 to summer 1997), the kelp assemblage formed by $M$. integrifolia and $L$. trabeculata at Caleta Constitución was distributed from 2 to $15 \mathrm{~m}$ depth, although the two kelp species demonstrated different bathymetric distributions. The maximum abundance of $M$. integrifolia occurred at onshore depths, between 5-8 m, while the maximum abundance of $L$. trabeculata occurred between 8 and $13 \mathrm{~m}$ (Fig. 3A). Between 9 and $11 \mathrm{~m}$ depth, both kelp species reached similar abundances (Fig. 3A). The percentage of consolidated rocky substratum per sampling unit was correlated significantly and positively with kelp abundance (Pearson $\mathrm{r}$ $=0.74, \mathrm{P}<0.001)$. There were no significant temporal modifications in the form of the 
substrate during the study period over the length of the bathymetric gradient studied. The density of $M$. integrifolia decreased in shoal bottoms onshore as the percentage of barren ground covered with crustose coralline algae increased (Fig. 3B). In contrast, from $13 \mathrm{~m}$ depth to offshore, the frequency of shell sand increased, marking the deeper limit of kelp distribution due to a decrease in consolidated rocky bottom (Fig. 3B). At depths greater than $15 \mathrm{~m}$ shell sand completely covered the bottom and neither kelp species was present.
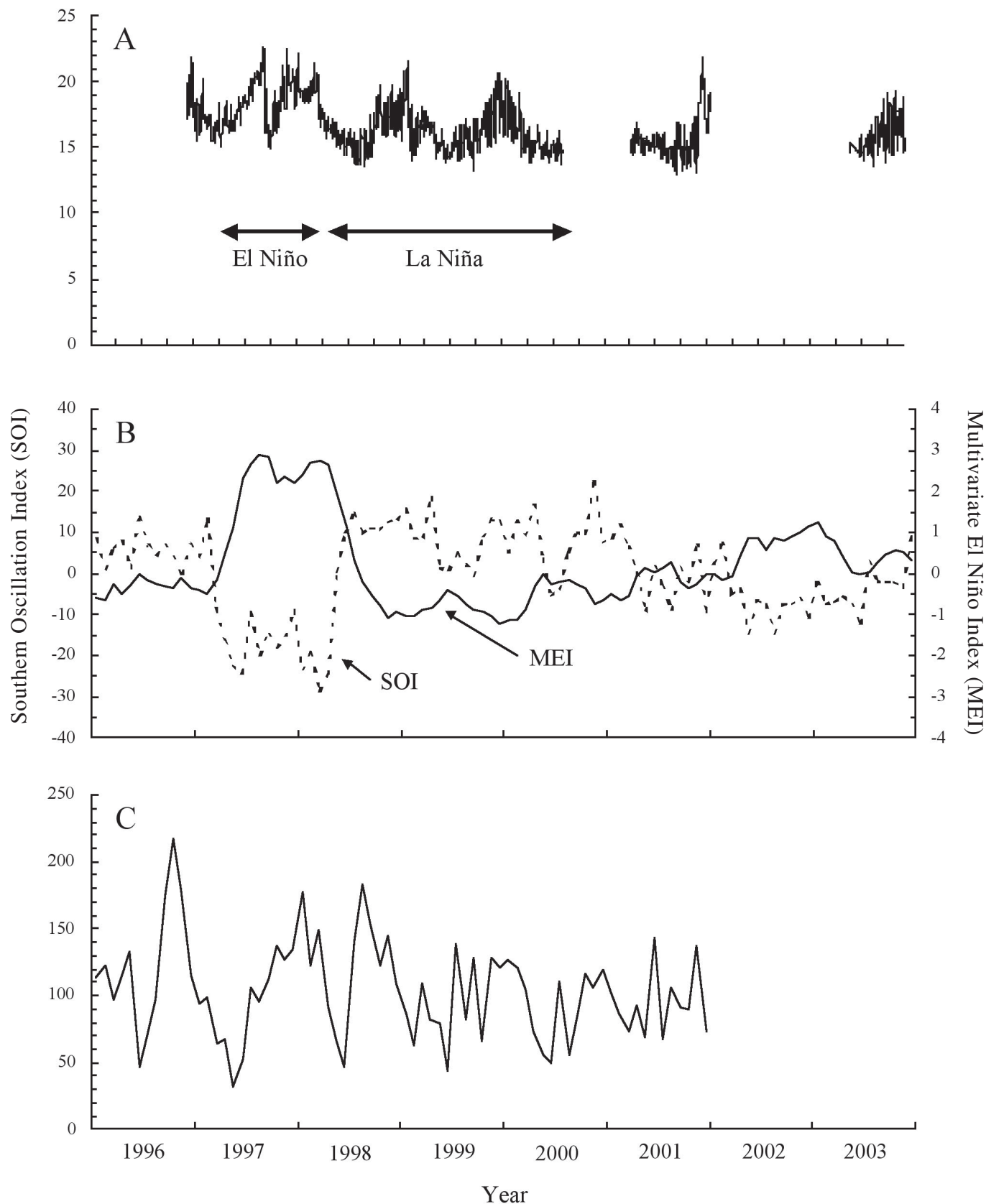

Fig. 2: Seawater temperature to $3 \mathrm{~m}$ depth into of kelp assemblage (A), Multivariate El Niño (MEI) and Southern Oscillation (SOI) indexes (B), and upwelling index (Eckman transport, OET) (C) during the study period.

Temperatura del agua de mar a $3 \mathrm{~m}$ de profundidad dentro del ensamble de huiros (A), índices Multivariado de El Niño (MEI) y de la Oscilación del Sur (SOI) (B) y índice de surgencia (Transporte de Ekman, OET) (C) durante el período de estudio. 

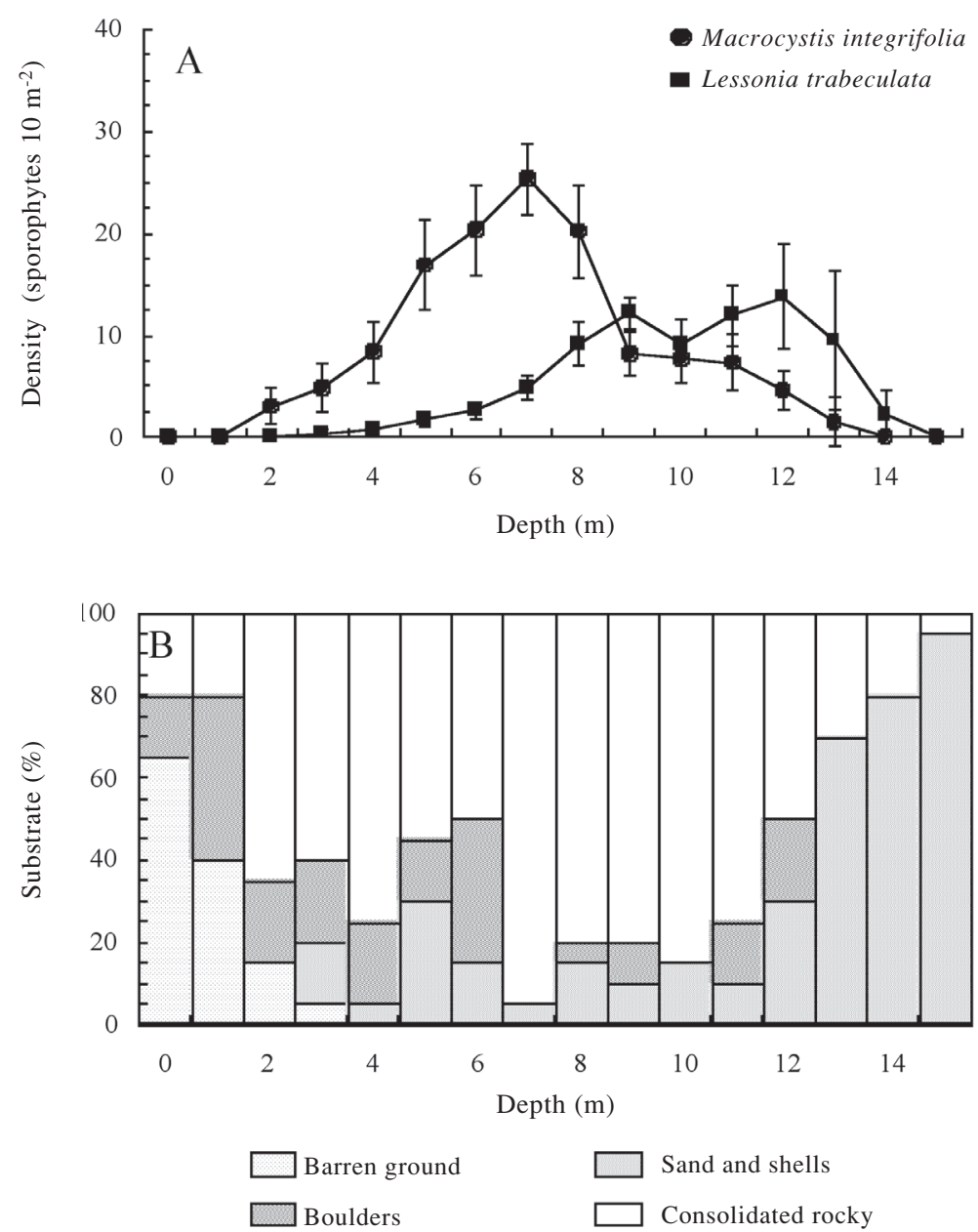

Fig. 3: Spatial patterns of abundance of adult sporophytes of Macrocystis integrifolia and Lessonia trabeculata (A) and relative frequency of different substrates across the bathymetric profile in the study area (B) in no El Niño condictions between 1996-1997. Data are means \pm SD.

Patrones espaciales de la abundancia de esporofitos adultos de Macrocystis integrifolia y Lessonia trabeculata (A) y frecuencia relativa de los distintos sustratos a lo largo del perfil batimétrico en el área de estudio (B), durante condiciones no El Niño entre 1996-1997. Los datos corresponden a medias \pm DE.

Patterns of temporal distribution of subtidal kelp assemblages

The density of $M$. integrifolia adult sporophytes differed significantly $\left(\mathrm{F}_{6,21}=35.40 ; \mathrm{P}<0.001\right)$ between years in which measurements were made (Fig. 4A). The seasonal patterns of abundance of adult sporophytes differed significantly among years $\left(\mathrm{F}_{21,84}=8.57, \mathrm{P}<0.001\right)$, particularly during the 1997-1998 (El Niño event) and the 1999-2000 (La Niña event). Paradoxically the passage of the 1997-1998 El Niño coincided with an increase in the abundance of adult sporophytes of M. integrifolia. Between fall 1999 and spring 2000 (Fig. 4B) no M. integrifolia juveniles were observed in the sampling units $\left(10 \mathrm{~m}^{2}\right)$, not in the study area, where additional exploratory diving was carried out. Aside from this period, juvenile $M$. integrifolia were present throughout the year without a defined seasonal pattern (Fig. 4B). Significant seasonal increases or decreases $\left(\mathrm{F}_{18,72}\right.$ $=5.63, \mathrm{P}<0.001)$ in the long term abundances of juveniles appeared to be determined by the intensity of upwelling events during the 19971998 El Niño, based on the significant decreases in adult sporophytes (1999) and characteristics of the re-establishment process of the M.integrifolia population (2001-2003).

Seasonal patterns in the abundance of adult L. trabeculata sporophytes differed significantly 
$\left(\mathrm{F}_{21,84}=88.18, \mathrm{P}<0.001\right)$ between years, but in contrast with $M$. integrifolia, the population maintained a mean annual abundance of about $3.9 \pm 1.5$ plants per $10 \mathrm{~m}^{2}$ over the entire period of the study. The 1997-1998 El Niño negatively affected the abundance of $L$. trabeculata in spring 1997 and summer 1998, while the 19982000 La Niña increased the abundances (Fig. 4C). The abundance of juveniles $L$. trabeculata was significantly higher in spring $\left(\mathrm{F}_{21,84}=\right.$ 193.95, $\mathrm{P}<0.001)$. In spite of the preceding, the re-establishment of adult sporophytes after the 1997-1998 El Niño and the mortality of these plants due to herbivore pressure (1999-2001) modified the seasonal pattern of abundance of juveniles between years (Fig. 4D).

Interannual variability of spatial patterns of subtidal kelp assemblages

The disjunct pattern of distribution of kelp over the bathymetric profile was persistent over the eight years of the study. Nevertheless, the spatial patterns of abundance of the adult and juvenile sporophytes of $M$. integrifolia over the bathymetric gradient differed for adult and juvenile sporophytes among years (Fig. 5). The continuous incorporation of $M$. integrifolia juveniles to the system between 1996 and 1999 permitted the maintenance of spatial distribution patterns of the adult sporophytes. Although during the transition period between the El Niño and La Niña events (1998) an increase was detected in juveniles over the length of the bathymetric profile, the patterns of distribution and abundance of the adult sporophytes were not altered during the following year (1999). During 2000 a few shoal adult sporophytes (1-2 m depth) remained under the L. trabeculata canopy (> $10 \mathrm{~m}$ depth) in the study area; in contrast, no sporophyte juveniles were detected (Fig. 5). Reestablishment of the subtidal kelp $M$. integrifolia occured by successful recruitment, demonstrated
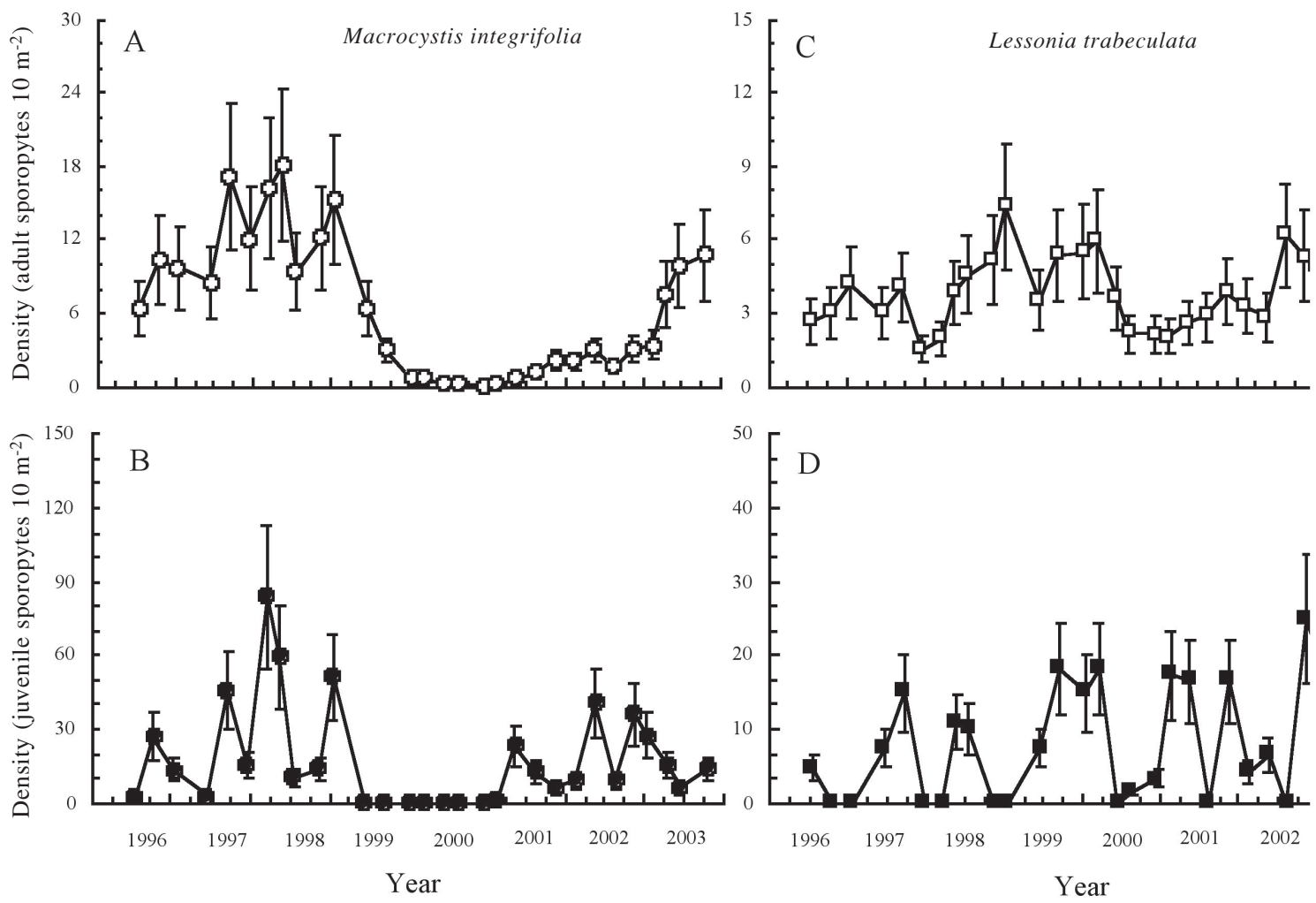

Fig. 4: Temporal patterns in the abundance of adult (A) and juvenil (B) of sporphytes of Macrocystis integrifolia and adult (C) and juvenil (D) of sporophytes of Lessonia trabeculata. Data are means \pm 2 EE.

Patrones temporales en la abundancia de esporofitos adultos (A) y juveniles (B) de Macrocystis integrifolia y de esporofitos adultos (C) y juveniles (D) de Lessonia trabeculata. Los datos corresponden a medias \pm 2 EE. 
by the establishment of juveniles which surrounded the few surviving adult sporophytes, and generating a nucleus which expanded towards the extremes of the bathymetric gradient (2001, Fig. 5). New recruitment of juvenile sporophytes in following years expanded the kelp (e.g., 2002-2003), until a kelp forest was formed which was similar to that observed at the beginning of this study (Fig. 3 and 5).

The patterns of abundance of the adult and juvenile sporophytes of L. trabeculata differed over the bathymetric gradient between years (Fig. 6). The spatial pattern of abundance of $L$. trabeculata became modified during 2000 at the end of the 1998-2000 La Niña and not during the 1997-1998 El Niño (Fig. 6). Over the eight years of the study, the maximum abundances of adult sporophytes occured at the limits of depth of its distribution, with the juveniles occurring over the entire bathymetic distribution of this kelp (Fig. 6).

\section{Reproductive phenology of subtidal kelp assemblages}

Adult sporophytes of $M$. integrifolia and $L$. trabeculata with reproductive structures (sporophylls and sori on the fronds, respectively) were present throughout the entire study period (Fig. 7). During the 1997-1998 El Niño, the percentage of reproductive plants of both kelp species remained above $70 \%$. During the 1999-

Macrocystis integrifolia
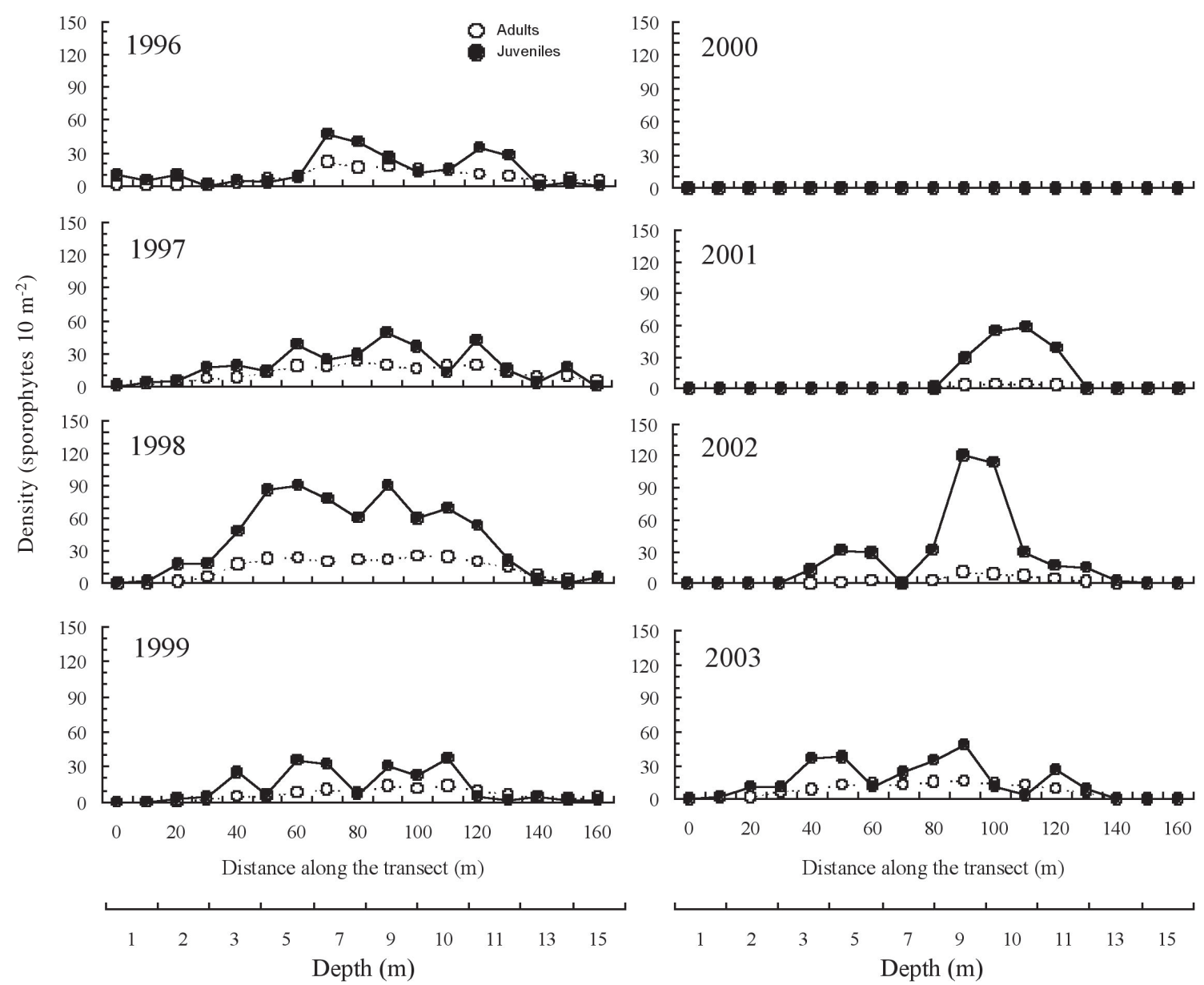

Fig. 5: Interannual variability patterns in the average abundance of adult and juveniles sporophytes of Macrocystis integrifolia along bathimetric profile.

Patrones de variabilidad interanual de la abundancia promedio de esporofitos adultos y juveniles de Macrocystis integrifolia a lo largo del perfil batimétrico. 
2000 La Niña, all of the few sporophytes of $M$. integrifolia (average densities of 0.1 to 0.6 individuals $10 \mathrm{~m}^{-2}$ ) were reproductive (Fig. 7A), while the percentage of fertile sporophytes of $L$. trabeculata remained above $75 \%$ (Fig. 7B). During 2001-2002 the percentage of fertile soporophytes of $M$. intergrifolia was less, as a consequence of the increases in infertile juvenile sporophytes as the population became reestablished (Fig. 7A). Between 2001 and 2003 the decrease in fertile L. trabeculata sporophytes by incorporation of juveniles was markedly seasonal (summer-fall 2001, and fall 2003), however, the frequency of reproductive plants was maintained over $50 \%$ (Fig. 7B).

\section{Herbivore-kelp interactions}

The sea urchin $T$. niger was the most conspicuous herbivore at Caleta Constitución, coexisting with another, less abundant urchin, $L$. albus. The temporal patterns of abundance of $T$. niger showed three significant $\left(\mathrm{F}_{6,21}=18.032, \mathrm{P}\right.$ $<0.001$ ) maxima over the study period, which were different from each other (Fig. 8). The sea urchins showed low levels of abundance between 1996 and 1999, including the 19971998 El Niño (Fig. 8). During the 1998-2000 La Niña (fall 1999-spring 2000) the mean density of black urchins increased three fold between 1996 and 1998 (Fig. 8). During 2000 the black sea

Lessonia trabeculata

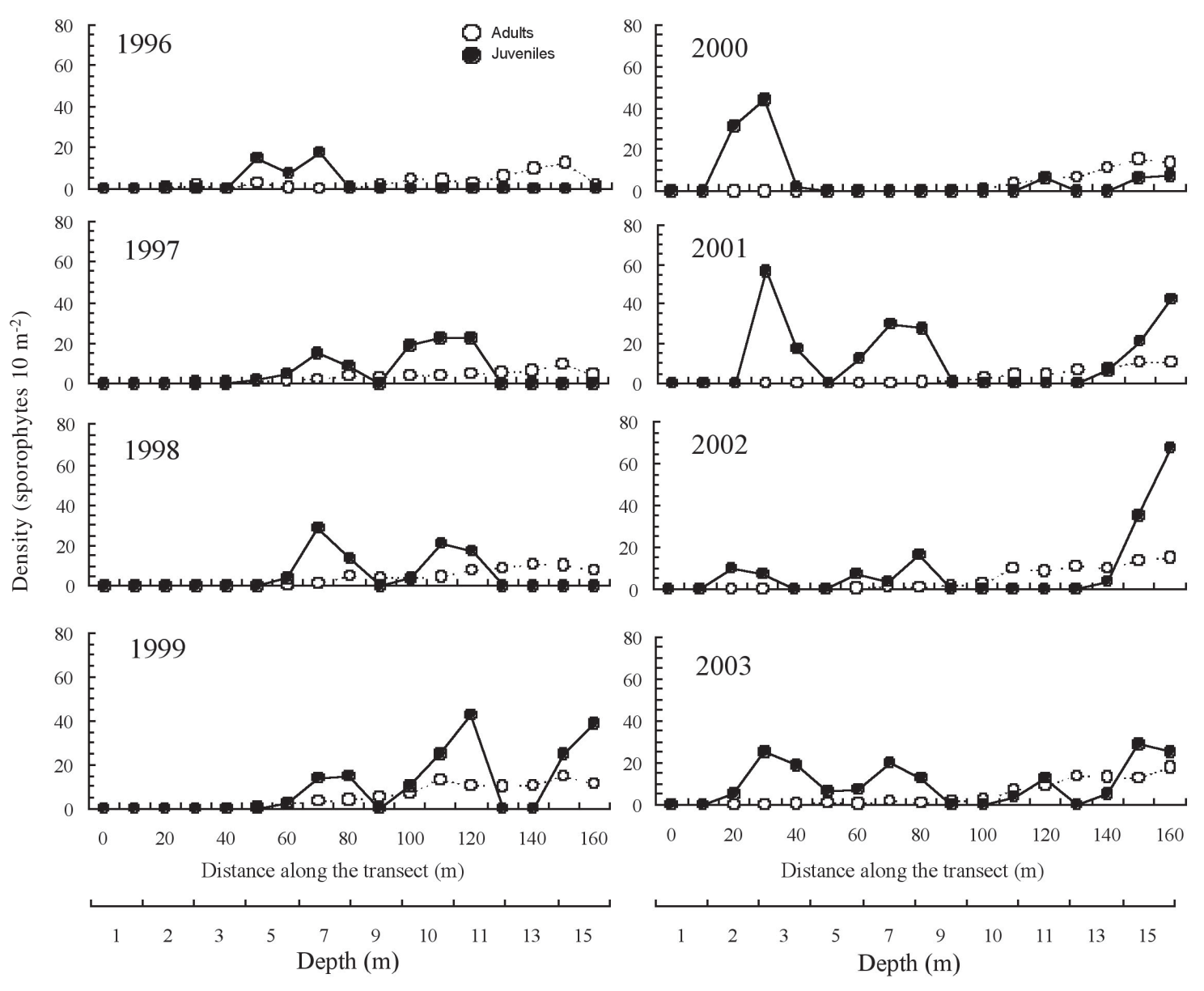

Fig. 6: Interannual variability patterns in the average abundance of adult and juveniles sporophytes of Lessonia trabeculata along bathimetric profile.

Patrones de variabilidad interanual de la abundancia promedio de esporofitos adultos y juveniles de Lessonia trabeculata a lo largo del perfil batimétrico. 
urchins formed herds over hard substrates at shoal depths from 8 to $10 \mathrm{~m}$ depth. This change in spatial-temporal patterns of abundance of $T$. niger coincided with the local extinction of the $M$. integrifolia population and the decrease in abundance of L. trabeculata at its depth limit. An inverse and significant correlation suggested that the density of juvenile and adult $M$. integrifolia sporophytes decreased with an increase in abundance of $T$. niger (Tabla 1). In contrast, non-significant correlations occurred between $T$. niger and L. trabeculata or between L. albus and both kelp species (Tabla 1). Beginning in 2001, the abundance of $T$. niger began to decrease until the end of 2003, giving values similar to those encountered between 1996 and 1999 (Fig. 8).

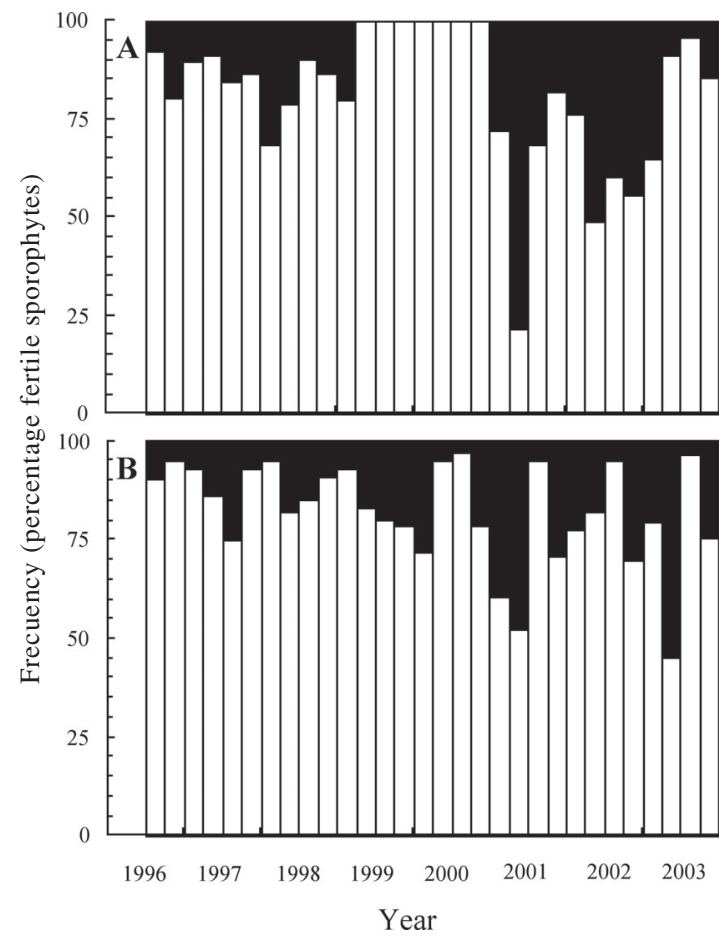

Fig. 7: Reproductive frecuencies of sporophytes of Macrocystis integrifolia (A) and Lessonia trabeculata (B) during study period. White bars indicate fertile sporophytes and black bars indicate infertile sporophytes.

Frecuencia de esporofitos reproductivos de Macrocystis integrifolia (A) y Lessonia trabeculata (B) durante el periodo de estudio. Barras blancas indican esporofitos fértiles y barras negras indican esporofitos sin estructuras reproductivas.
TABLE 1

Pearson correlation coefficient (probability in paréntesis) between sea urchins and kelp abundance. Significant association at alpha $=0.05$

Coeficiente de correlación de Pearson (probabilidad en paréntesis) entre erizos de mar y abundancia de huirales Asociaciones significativas a un alfa $=0,05$

\begin{tabular}{lcc}
\hline & $\begin{array}{c}\text { Tetrapygus } \\
\text { niger }\end{array}$ & $\begin{array}{c}\text { Loxechinus } \\
\text { albus }\end{array}$ \\
\hline Macrocystis integrifolia & & \\
Adults & -0.67 & -0.17 \\
Juveniles & $(0.0001)$ & $(0.3631)$ \\
& -0.51 & 0.06 \\
Lessonia trabeculata & $(0.0036)$ & $(0.7374)$ \\
Adults & & \\
& -0.22 & 0.30 \\
Juveniles & $(0.2343)$ & $(0.1075)$ \\
& -0.36 & 0.25 \\
& $(0.0507)$ & $(0.1868)$ \\
\hline
\end{tabular}

Morphological variability of Lessonia trabeculata in subtidal kelp assemblage

We observed two different morphologies of $L$. trabeculata as previously described by Vásquez (1992) within the assemblage of subtidal kelp over the bathymetric gradient at Caleta Constitución. These included a "bushy" morph consisting of sporophytes with large numbers of small stipes, where the total weight of the plant was distributed among the many, highly flexible stipes. A second "arborescent" morph, was formed of sporophytes with few, long, thick stipes in which the weight of the plant was concentrated; these stipes showed little flexibility. Discriminate function analysis showed the number of stipes and the maximum diameter of the holdfast to be the main functions useful in discriminating between the two Lessonia morphs. L. trabeculata sporophytes with the bushy morph occurred mostly in stands dominated by M. integrifolia (Fig. 9). Conversely, monospecific beds of $L$. trabeculata were made up of sporophytes with the arborescent morphology (Fig. 9), particularly at the deeper limits of their distribution. The bathymetric distribution pattern of the bushy and arborescent morphs of $L$. trabeculata found within the kelp assemblage from 1996 to 1999 was re-established at the end of the study period (winter and spring 2003). 


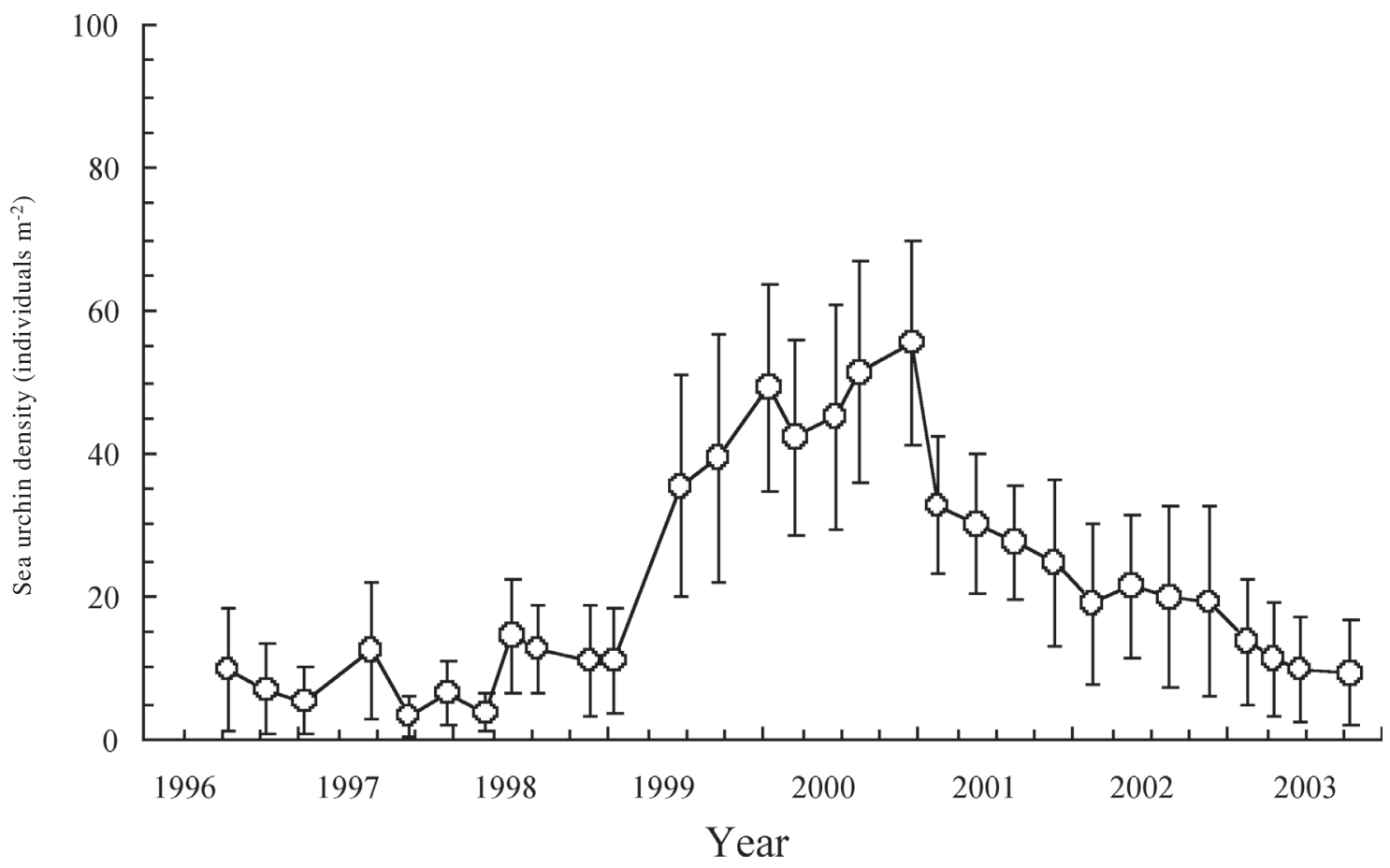

Fig. 8: Temporal patterns in the abundance of Tetrapygus niger. Data are means $\pm 2 \mathrm{EE}$.

Patrones temporales en la abundancia de Tetrapygus niger. Los datos corresponden a media $\pm 2 \mathrm{EE}$.

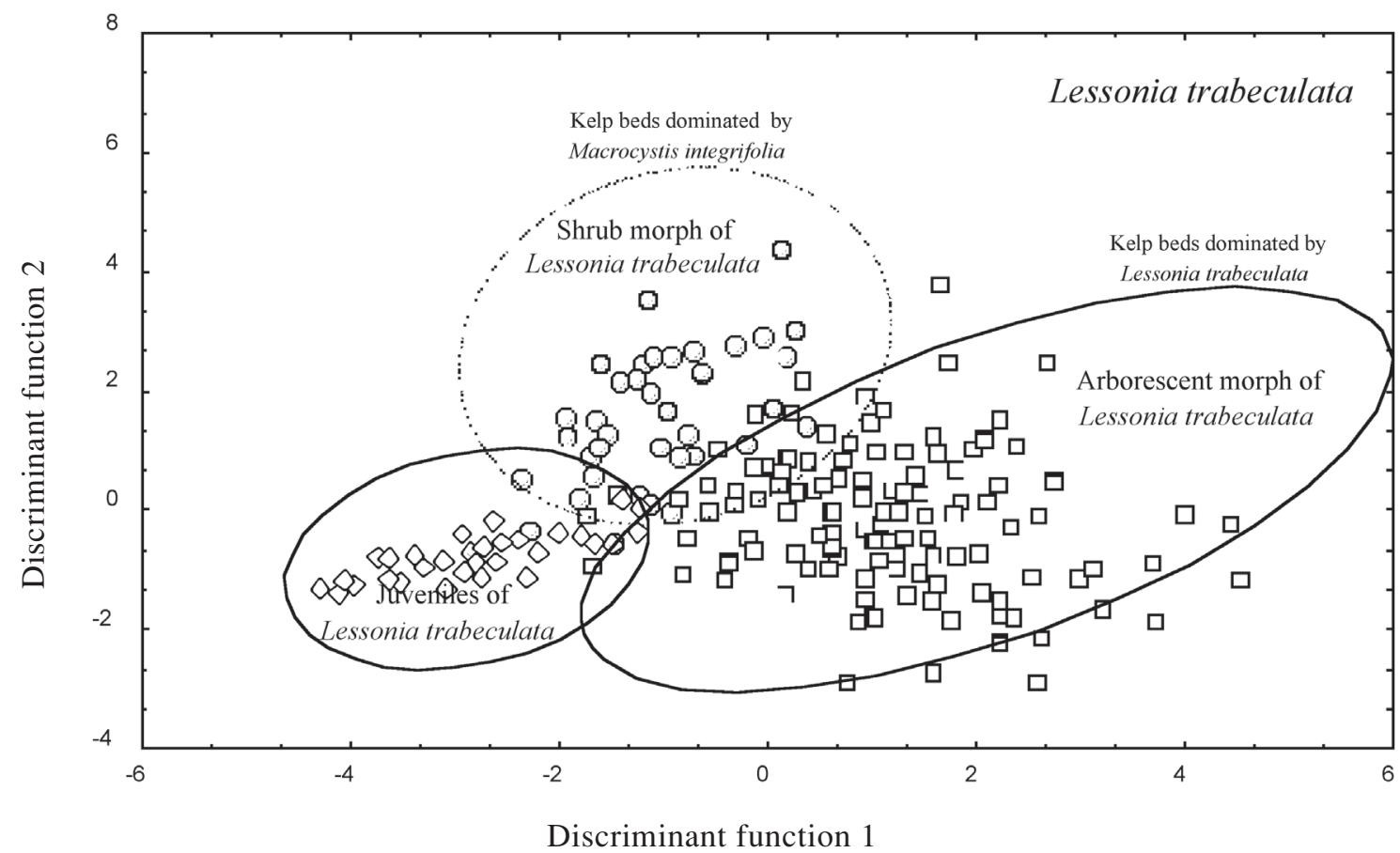

Fig. 9: Analysis of discriminate functions using five morphological parameters to differentiate juvenile and adult plants of Lessonia trabeculata in presence/absence of Macrocystis integrifolia.

Análisis de funciones discriminantes usando cinco parámetros morfológicos para diferenciar de plantas juveniles y adultas de Lessonia trabeculata en presencia/ausencia de Macrocystis integrifolia. 


\section{DISCUSSION}

The structure of subtidal kelp assemblages on the exposed rocky shores of northern Chile is simple, and represented by monospecific stands of bottom kelp L. trabeculata (Villouta \& Santelices 1984, Vásquez 1992, Tala et al. 2004). On semi-exposed and protected subtidal rocky shores, $M$. integrifolia forms the canopy that grows to the surface while the bottom kelp, L. trabeculata, forms the sub-canopy, although with disjunct distributions over the bathymetric gradient. This is in contrast to subtidal kelp assemblages found at equivalent latitudes in the Northern Hemisphere, where there is hierarchical organization through interspecific competition among the several components of kelp forests (Dayton et al. 1992, 1999, Tegner et al. 1997).

Spatial patterns of abundance in subtidal kelp assemblages

It has been proposed that the segregated patterns of bathymetric distribution in kelp assemblages are a reflection of species-specific morphological adaptations to wave exposure (Santelices \& Ojeda 1984, Druelh \& Kemp 1986, Utter \& Denny 1996), species-specific physiological adaptations based on light and nutrient requirements for photosynthesis and/or growth (Druelh 1978, Gómez et al. 1997, Apprill \& Lesser 2003), and on endogenous factors such as circadian or circannual rhythms that respond differentially to environmental changes (Schaffelke \& Lünning 1994). Interspecific competition has also been suggested as a structural agent in kelp assemblages over bathymetric gradients (Reed \& Foster 1984, Santelices \& Ojeda 1984, Tegner et al. 1997). At Caleta Constitución, the higher rate of colonization and growth of $M$. integrifolia during 2002-2003 produced a negative effect on the recruitment and growth of L. trabeculata juveniles between 2 and $7 \mathrm{~m}$ depth. This appears to induce a modification of the morphology of the adult sporophytes of $L$. trabeculata under the $M$. integrifolia canopy. The potential effect of a $M$. integrifolia stand in reducing wave action and this, in turn, influencing $L$. trabeculata morphology instead of or in addition to competition must be explored. Hypotheses that explain the patterns of distribution of $M$. integrifolia and $L$. trabeculata over bathymetric gradients are not exclusive. Species-specific morphological and/ or physiological adaptations, as well as interspecific competition may interact at different depth levels of the assemblage to produce a segregated pattern of distribution, generating different morphs of L. trabeculata over the range of bathymetric distribution. This hypothesis needs to be tested in the future by means of in situ experimental removal and competitive exclusion experiments, in order to evaluate recruitment and species-specific growth rates.

\section{Temporal patterns of abundance in subtidal kelp assemblages}

The abundances of $M$. integrifolia and $L$. trabeculata differed markedly between years during the study period. These annual differences are a reflection of modifications in seasonal patterns of both kelps. Temporal variations in the abundances of kelp in temperate environments of the Northern Hemisphere are correlated with thermal anomalies coupled to annual temperature oscillations. These co-vary inversely with the availability of nutrients (Dayton et al. 1992), generating different seasonal patterns of abundance (Dayton et al. 1999). Nevertheless, physical, (e.g., storms and swells) and/or biological (e.g., pests, herbivory) disturbances of low frequency and intensity produce breaks in spatial-temporal distributions (Tegner et al. 1987, Dayton et al. 1998), adding additional randomness to long-term patterns of abundance. Populations of $M$. integrifolia and $L$. trabeculata in northern Chile are formed by perennial and long-lived sporophytes, which maintain their levels of abundance during the year, with seasonal variability in growth and reproduction (Buschmann et al. 2004, Tala et al. 2004). This apparent temporal stability (annual variability) in the population dynamics of the South American kelp is, however, interrupted (interannual variability) by: (1) positive thermal anomalies during El Niño, which generate mortalities correlated with latitude (Tomicic 1985, Camus 1994, Godoy 2000), and (2) site-dependent recolonization events of varying intensity during cool and normal years (Camus 1994, Martínez et al. 
2003). In this context, our results have shown that in the study area: (1) during the 1997-1998 El Niño the patterns of abundance of both kelp did not change significantly, (2) kelp productivity during the 1998-2000 La Niña event was reduced to minumum levels due to the extinction of $M$. integrifolia in shallow depths and decrease in abundance of $L$. trabeculata, and (3) the re-establishment of the kelp assemblage occurred post La Niña, during the mild, and poorly documented 2002-2003 El Niño event.

The temporal pattern of recruitment of sporophytes differed between the two kelps. While $M$. integrifolia showed recruitment throughout the year (as in other wave-protected environments, see Graham et al. 1997), $L$. trabeculata showed seasonal recruitment during the winter, producing greater abundance of juveniles during the spring. These differences in recruitment pattern (annual versus seasonal) imply differing reproductive strategies between the kelp species, which may in part explain the temporal dynamics of the assemblage and require clarification through application of experimental protocols in the future.

Spatial-temporal patterns of distribution in subtidal kelp assemblages

Spatial-temporal patterns of distribution and abundance of $M$. integrifolia and L. trabeculata did not become significantly modified during the 1997-1998 El Niño.This is in contrast with local extinction processes during this El Niño documented for other kelp-dominated areas in Peru and Chile (Fernández et al. 1999, Godoy 2000, Lleellish et al. 2001) and California (Ladah et al. 1999, Edwards 2004). The persistence of spatial and temporal patterns in kelp assemblages during the 1997-1998 El Niño in the study area may be explained by the frequency and intensity of coastal upwelling (González et al. 1998, Vásquez et al. 1998, Lagos et al. 2002), which buffers and minimizes superficial heating of the sea and impoverishment of nutrients in littoral waters (González et al. 1998, Takesue et al. 2004). Based on our results it can be suggested that the persistence of kelp populations in the above mentioned upwelling areas during the 19971998 El Niño might function as local "sources" which "export" propagules to other localities "sinks" without upwelling where mass mortalities have occurred (Camus 1994).

The recovery rate of kelp populations in localities in which extinction processes occurred as a result of the El Niño is favored when there is a rapid transition to cool periods or La Niña (Edwards 1994). La Niña conditions reinforce coastal upwelling processes, generating conditions favorable for the growth and development of juvenile kelp sporophytes (Tegner et al. 1987, Dayton et al. 1998). During the period of the present study, La Niña (19982000) conditions occurred almost immediately after passage of the 1997-1998 El Niño. However, the spatial-temporal pattern of distribution de $M$. integrifolia and $L$. trabeculata became modified in the study area during the 1998-2000 La Niña due to significant changes in the patterns of distribution and abundance of the sea urchin $T$. niger during 1999-2000.

\section{Kelp-herbivore interactions}

An increase in grazing pressure was documented as simultaneously occurring with warming of coastal surface waters at low latitudes $\left(10-23^{\circ} \mathrm{S}\right)$ of both Hemispheres during the 1997-1998 El Niño (Halpin et al. 2004). In this context, positive thermal anomalies and bathymetric migrations of grazers produce a sinergistic effect, causing local extinctions of Macrocystis spp. (Godoy 2000, Llellish et al. 2001), and decreases in the bathymetric range of $L$. trabeculata (Fernández et al. 1999, Vásquez \& Vega 2004). In contrast, the present study showed an absence of local extinctions during the 1997-98 El Niño. A combination of "topdown" and "bottom-up" effects appear to regulate these ecosystemic changes, including (1) the 1997-1998 El Niño significantly decreased the density of starfish between 2 and $10 \mathrm{~m}$ depths, the bathymetric range with the highest density of $M$. integrifolia (Vásquez \& Vega 2004). These benthic organisms form the most important guild of carnivores on the SE Pacific coastline (Vásquez \& Buschmann 1997). (2) Warming of surface waters in the study area, moderated by upwelling events during 1997-1998, induced many sea urchin spawnings which produced successful 
recruitment during the 1999-2000 La Niña (Vásquez \& Vega 2004); (3) the dephase in local extinction of kelp populations two years after the 1997-1998 El Niño occurred atypically during the 1999-2000 La Niña. The mass mortality of $M$. integrifolia in the study area thus seems to be a consequence of the relation of predator-prey abundances. Topdown and bottom-up regulation generated by the El Niño in communities dominated by Macrocystis pyrifera in California have recently been reviewed by Halpin et al (2004).

The survival of a few fertile sporophytes after local extinctions of $M$. integrifolia in 2000 appears to have been the main source of reproductive propagules for the reestablishment of the subtidal assemblage at Caleta Constitución. Drifting rafts of kelp, and "seed banks" of microscopic dormant stages may be considered as complementary strategies for the re-establishment of assemblages of kelp (Dayton et al. 1992, Ladah et al. 1999, Buschmann et al. 2004, Edwards 2004)

Centers of upwelling may act to modify the littoral biota, but in contrast with El Niño events, they act on a local scale. Permanent upwelling has an upwardly cascading or "bottom-up" regulation of the communities on coastal ecosystems (Vásquez et al. 1998, Camus \& Andrade 1999, Nielsen \& Navarrete 2004). The permanent subsidy of nutrient-rich waters and low temperature has been considered important factors in the increase in biodiversity and productivity of coastal zones where it occurs (Bosman et al. 1987, Ormond \& Banaimoon 1994, Nielsen \& Navarrete 2004). Our study suggests, as well, that areas with permanent upwelling decrease the effects of upper-layer warming generated by highintensity El Niño events, permitting the persistence of kelp populations. Here, the correspondence between intensity and frequency of coastal upwelling during El Niño events may explain variability among effects produced in coastal communities by this oceanographic event. In the present study area, the 1982-1983 El Niño caused mass mortalities of intertidal and subtidal kelp (Tomicic 1985), with a recovery time of over 10 years (Martínez et al. 2003). In contrast, superficial warming during the 1997-1998 El Niño did not modify the spatial and temporal patterns of the coastal kelp assemblages at Caleta Constitución.
Infrequent and hard-to-predict disturbances, such as the significant increase in herbivores during the 1998-2000 La Niña event, further add randomness to the spatial-temporal patterns of the distribution and abundance of organisms inhabiting communities dominated by kelp. Other poorly predictable biological disturbances that document changes in patterns of abundance and distribution of kelp species include pests (Graham et al. 1997), and mass mortalities of benthic grazers (Dayton et al. 1998), as well as mortalities of high-level predators (Estes et al. 1998). Although coastal upwelling processes and large-scale oceanographic events such as El Niño and La Niña produce local variability, their effects have been studied and documented separarely both on a temporal and spatial basis. Our results suggest the need for maintaining longterm studies, which allow integration of physical and biological processes on a local scale (e.g., upwelling, predator-prey interactions, plant-plant interactions, pests, mass mortalities), with low frequency, largescale climatic event (El Niño-La Niña).

\section{ACKNOWLEDGEMENTS}

The authors are thankful for the collaboration received from D. Veliz, L.M. Pardo, C. Cerda, F. Veliz, J. Rivera, N. Godoy, E. Rojas, C. Ibacache, P. Bravo and N. Piaget during the demanding days of diving research. Also the authors thank S. Navarrete, M. Graham, M. Edwards and one anonymous reviewer for helpful comments on the manuscript. This work was supported by FONDECYT-SECTORIAL 5960001, FONDAP 0 \& $\mathrm{BM} \mathrm{N}^{\circ} 3$, FONDECYT 1000044-1010706. This research is part of Masters of Science Thesis of the first author, in the Master Program in Marine Sciences at the UCN.

\section{LITERATURE CITED}

ALVEAL K, H ROMO \& J VALENZUELA (1973) Consideraciones ecológicas de las regiones de Valparaíso y de Magallanes. Revista de Biología Marina (Chile) 15:1-29.

APPRILL AM \& MP LESSER (2003) Effects of ultravioleta radiation on Laminaria saccharina in relation to depth and and tidal height in the Goulf of Main. Marine Ecology Progress Series 256: 75-85. 
BOSMAN AL, PAR HOCKEY \& WR SIEGFRIED (1987) The influence of coastal upwelling on the functional structure of rocky intertidal communities. Oecologia 72: 226-232.

BUSCHMANN A, JA VÁSQUEZ, P OSORIO, E REYES, L FILUN, MC HERNÁNDEZ-GONZÁLEZ \& A VEGA (2004) The effect of water movement, temperature and salinity on abundance and reproductive patterns of Macrocystis spp. (Phaeophyta) at different latitudes in Chile. Marine Biology 145: 849-862

CAMUS PA (1990) Procesos regionales y fitogeografía en el Pacífico Suroriental: el efecto de "El NiñoOscilación del Sur". Revista Chilena de Historia Natural 63: 11-17. 1990.

CAMUS PA (1994) Dinámica geográfica en las poblaciones de Lessonia nigrescens Bory (Pheophyta) en el norte de Chile: importancia de la extinción local durante eventos El Niño de gran intensidad. Revista de Investigaciones Científicas y Tecnológicas, Serie Ciencias del Mar (Chile) 3: 58-70.

CAMUS PA \& AN ANDRADE (1999) Diversidad de comunidades intermareales rocosas del norte de Chile y el efecto potencial de la surgencia costera. Revista Chilena de Historia Natural 72: 389-410.

CAMUS PA, EO VÁSQUEZ, EO GONZÁLEZ \& LE GALAZ (1994) Fenología espacial de la diversidad intermareal en el norte de Chile: Patrones comunitarios de variación geográfica e impacto de los procesos de extinción y recolonización post El Niño 82/83. Medio Ambiente (Chile) 12: 57-68.

DAYTON PK (1985) The structure and regulation of some south American kelp communities. Ecological Monographs 55: 447-468.

DAYTON PK, MJ TEGNER, PE PARNELL \& PB EDWARDS (1992) Temporal and spatial patterns of disturbance and recovery in kelp forest community. Ecological Monographs 62: 421-445.

DAYTON PK, MJ TEGNER, PB EDWARDS \& K RISER (1998) Slinding, ghost, and reduced expectations in kelp forest communities. Ecological Applications 8: 309-322.

DAYTON PK, MJ TEGNER, PB EDWARDS \& KL RISER (1999) Temporal and spatial scales of kelp demography: the role of oceanographic climate. Ecological Monographs 69: 219-250.

DIECK TI (1993) Temperature tolerance and survival in darckness of kelp gametophytes (Laminariales, Phaeophyta): ecological and biogeographical implications. Marine Ecology Progress Series 100: 253-264.

DRUELH LD (1978) The distribution of Macrocystis integrifolia in British Columbia as related to enviroment parameters. Canadian Journal of Botany 567: 69-79.

DRUELH LD \& L KEMP (1986) Morphological and growth responses of of geographically isolated Macrocystis integrifolia populations when grown in a common enviroment. Canadian Journal of Botany 60: 1409-1413

EDWARDS MS (2004) Estimating scale-dependency in disturbance impacts: El Niño and giant kelp forests in the northeast Pacific. Oecologia 138: 436-447.

ESCRIBANO R (1998) Population dynamics of Calanus chilensis in the Chilean eastern boundary Humboldt current. Fiheries Oceanography 7: 245-251.

ESCRIBANO R \& IA MCLAREN (1999) Producción of Calanus chilensis in the upwelling area of Antofagasta, northern Chile. Marine Ecology Pregress Series 177: 147-156.
ESCRIBANO R, SA ROSALES \& JL BLANCO (2004) Understanding upwelling circulation off Antofagasta (northern Chile): a three-dimensional numerical-modeling approach. Continental Shelf Research 24: 37-53.

ESTES JA, MT TINKER, TM WILLIAMS \& DF DOAK (1998) Killer whale predation on sea otter linking oceanic and nearshore ecosystem. Science 282: 473-476.

FERNÁNDEZ E, C CÓRDOVA \& J TARAZONA (1999) Condiciones del bosque submareal de Lessonia trabeculata en la Isla Independencia durante el evento El Niño 1997-1998. Revista Peruana de Biología, Volumen Extraordinario: 47-59.

GÓMEZ I, G WEYKAM, H KLÖSER \& H WIENCKE (1997) Photosybthetic lights requeriment s, metabolic carbon balance and zonation of sublittoral macroalgae in King George Island (Antártica). Marine Ecology Progress Series 148: 281-293.

GONZÁLEZ HE, VC ORTIZ \& M SOBARZO (2000) The role of faecal material in the particulate organic carbon flux in the northern Humboldt Current $\left(23^{\circ}\right.$ S) before and during the 1997-1998 El Niño. Journal of Plankton Research 22: 499-529.

GODOY NE (2000) Macrocystis integrifolia (Laminariales, Phaeophyta) en el norte de Chile: distribución espacial y fauna asociada. Tesis para optar al Título de Biólogo Marino, Facultad de Ciencias del Mar, Universidad Católica del Norte, Coquimbo, Chile. 58 pp.

GRAHAM MH, C HARROLD, S LISIN, K LIGHT, JM WATANABE \& MS FOSTER (1997) Populations dynamics of giant kelp Macrocystis pyrifera along a wave exposure gradient. Marine Ecology Progress Series 148: 269-279.

HALPIN PA, PT STRUB, WT PETERSON \& TR BAUMGARTNER (2004) An overview of interactions among oceanography, marine ecosystems, climatic and human disruptions along the eastern margins of the Pacific Ocean. Revista Chilena de Historia Natural 77: 371-410.

HERNÁNDEZ-CARMONA G, D ROBLEDO \& E SERVIERE-ZARAGOZA (2001) Effect of nutrient availability on Macrocystis pyrifera recruitment and survival near its sourthern limit off Baja California. Botánica Marina 44: 221-229.

KAIN JM (1989) The season in the subtidal. British Phicologycal Journal 24: 203-215.

KREBS CJ (1989) Ecological methodology. Harper Collins Publishers, New York, New York, USA. $654 \mathrm{pp}$.

LADAH LB, JA ZERTUCHE-GONZÁLEZ \& G HERNÁNDEZ-CARMONA (1999) Giant kelp (Macrocystis pyrifera, Pheophyceae) recruitment near its sourthern limit in baja california after mass dissapearance during ENSO 1997-1998. Journal of Phycology 35: 1106-1112.

LAGOS NA, ID BARRÍA \& P PAOLINI (2002) Upwelling ecosystem of northern Chile: integrating benthic ecology and coastal oceanography throught remote sensing. In: Castilla JC \& JL Largier (eds) The oceanography and ecology of the nearshore and bays in Chile: 117-141. Ediciones Universidad Católica de Chile, Santiago, Chile.

LLEELLISH J, E FERNÁNDEZ \& Y HOOKER (2001) Disturbancia del bosque submareal de Macrocystis pyrifera durante El Niño 1997-1998 en la Bahía de Pucusana. In: Alveal K \& $\mathrm{T}$ Antezana (eds) Sustentabilidad de la biodiversidad. Un problema actual: bases científico técnicas, teorizaciones y 
proyecciones: 331-350. Ediciones Universidad de Concepción, Concepción, Chile.

MARTÍNEZ EA (1999) Latitudinal differences in thermal tolerance among microcopic sporophytes of the kelp Lessonia nigrescens (Phaeophyta: Laminariales). Pacific Science 53: 74-81.

MARTÍNEZ EA, L CÁRDENAS \& R PINTO (2003) Recovery and genetic diversity of the intertidal kelp Lessonia nigrescens 20 years after El Niño 198283. Journal of Phycology 39: 504-508.

MARÍN VH, R ESCRIBANO, R DELGADO, LE OLIVARES \& G HIDALGO (2001) Nearshore circulation in a coastal upwelling site off the northern Humboldt Current System. Continental Shelf Research 21: 1317-1329.

MORENO C \& JP SUTHERLAND (1982) Physical and biological processes in a Macrocystis pyrifera community near Valdivia, Chile. Oecologia 55: 1-6.

NAVARRETE SA, B BROITMAN, EA WIETERS, GR FINKE, RM VENEGAS \& A SOTOMAYOR (2002) Recruitment of intertidal invertebrates in the southeast Pacific: interannual variability and the 1997-1998 El Niño. Limnology and Oceanography 47: 791-802.

ORMOND RFG \& SA BANAIMOON (1994) Ecology of intertidal macroalgae assemblages on the Hadramout coast of sourthern Yemen, an area of seasonal upwelling. Marine Ecology Pregress Series 105: 105-120.

REED DC \& MS FOSTER (1984) The effects of canopy shading on algal recruitment and growth in a giant kelp forest. Ecology 65: 937-948.

SANTELICES B \& FP OJEDA (1984) Population dynamic of coastal forest of Macrocystis pyrifera in Puerto Toro, Isla Navarino, sourthern Chile. Marine Ecology Progress Series 14: 175- 183.

STENSETH NC, G OTTERSEN, JW HURRELL, A MYSTERUD, M LIMA, K CHAN, NG YOCCOZ \& B ADLANDSVIK (2003) Studyng climate effects on ecology through the use of climate indices: the North Atlanthic Oscillation, El Niño Southern Oscillation and beyond. Proceedings of the Royal Society of London, Biological Sciences 270: 2087-2096.

SCHAFFELKE B \& K LÜNING (1994) A circannual rhythm controls seasonal growth in the kelps Laminaria hyperborea and L. digitata from Helgoland (North Sea). European Journal of Phycology 29: 49-56.

SCHEIBLING RE, AW HENNIGAR \& T BALCH (1999) Destructive grazing, epiphytism and disease: the dynamic of sea urchins-kelp interaction in Nova Scotia. Canadian Journal Fisheries and Aquatics Science 56: 1-15.

SOKAL RR \& FJ ROHLF (1981) Biometry: principles and practice of statistical in biological research. W.H. Freeman \& Company, San Francisco, California, USA. 776 pp.

SYSTAT (1992) Statistics. Version 8.0 ed. SYSTAT Inc., Evanston, Illinois, USA.

TALA F, M EDDING \& J VÁSQUEZ (2004) Aspect of the reproductive phenology of Lessonia trabeculata (Laminariales: Phaeophyceae) from three populations in northern Chile. New Zealand Journal of Marine and Freshwater Research 38: 255-266.

TAKESUE RK, A VAN GEEN, JD CARRIQUIRY, E ORTIZ, L GONIDEZ-ORTA, I GRANADOS, M SALDÍVAR, L ORTLIEB, N GUZMÁN, JC
CASTILLA, M VARAS, M SALAMANCA \& C FIGUEROA (2004) Influence of coastal upwelling and ENSO on nearshore water along baja California and Chile: shore-based monitoring during 19972000. Journal of Geophysical Research-Oceans 109: 3009, doi: 10.1029/2003JC001856.

TEGNER MJ, PK DAYTON, PB EDWARDS \& KL RISER (1997) Large-scale, low frequency oceanographic effects on kelp forest succession: a tale of two cohorts. Marine Ecology Progress Series 146: $117-134$

TOMICIC JJ (1985) Efectos del fenómeno de El Niño 1982-1983, en las comunidades litorales de la península de Mejillones. Investigaciones Pesqueras (Chile) 32: 209-213.

ULLOA O, R ESCRIBANO, S HORMAZÁBAL, R QUIÑÓNEZ, M RAMOS \& R GONZÁLEZ (2001) Evolution and biological effects of the 1997-1998 El Niño in northern Chile. Geophysical Research Letters 28: 1591-1594.

UTTER BD \& MW DENNY (1996) Wave-induced forces on the giant kelp Macrocystis pyrifera (Agardh): Field test of a computacional model. Journal of Experimental Biology 199: 2645-2654.

VÁSQUEZ JA (1991) Variables morfométricas y relaciones morfológicas de Lessonia trabeculata Villouta \& Santelices, 1986, en una población submareal del norte de Chile. Revista Chilena de Historia Natural 64: 271-279.

VÁSQUEZ JA (1992) Lessonia trabeculata, a subtidal bottom kelp in northern Chile: a case study for a structural and geographical comparason. In: Seeliger U (ed) Coastal plants of Latin America: 77-89. Academics Press, San Diego, California, USA.

VÁSQUEZ JA (1993) Patrones de distribución de poblaciones submareales de Lessonia trabeculata (Laminariales, Phaeophyta) en el norte de Chile. Facultad de Ciencias del Mar, Universidad Católica del Norte, Serie Ocasional (Chile) 2: 187-211

VÁSQUEZ JA \& A BUSCHMANN (1997) Herbivore-kelp interactions in Chilean subtidal communities: a review. Revista Chilena de Historia Natural 70: 4152.

VÁSQUEZ JA \& JMA VEGA (2004) El Niño 1997-1998 en el norte de Chile: efectos en la estructura y en la organización de comunidades submareales dominadas por algas pardas: 119-135. In: Avaria S, J Carrasco, J Rutland \& E Yáñez (eds) El Niño-La Niña 1997-2000 sus efectos en Chile. CONA, Valparaíso, Chile.

VÁSQUEZ JA, PA CAMUS \& FP OJEDA (1998) Diversidad, estructura y funcionamiento de ecosistemas rocosos del norte de Chile. Revista Chilena de Historia Natural 71: 479-499.

VÁSQUEZ JA，E FONCK \& JMA VEGA (2001) Diversidad, abundancia y variabilidad temporal de ensambles de macroalgas del submareal rocoso del norte de Chile. In: Alveal K \& T Antezana (eds) Sustentabilidad de la biodiversidad. Un problema actual: bases científico técnicas, teorizaciones y proyecciones: 351-365. Ediciones Universidad de Concepción, Concepción, Chile.

VILLOUTA E \& B SANTELICES (1984) Estructura de la comunidad submareal de Lessonia (Phaeophyta, Laminariales) en Chile norte y central. Revista Chilena de Historia Natural 57: 111-122. 